\title{
Article \\ Arbuscular Mycorrhizal Fungi Isolated from Highly Saline "Sabkha Habitat" Soil Alleviated the NaCl-Induced Stress and Improved Lasiurus scindicus Henr. Growth
}

\author{
Jahangir A. Malik ${ }^{1, *}$, AbdulAziz A. AlQarawi ${ }^{1}$, Basharat A. Dar ${ }^{1}{ }^{\circledR}$, Abeer Hashem ${ }^{2}$, Thobayet S. Alshahrani ${ }^{1}$, \\ Mashail N. AlZain ${ }^{3}$, Muhammad M. Habib ${ }^{1}$, Muhammad M. Javed ${ }^{1}$ and Elsayed Fathi Abd_Allah ${ }^{1} \mathbb{D}$ \\ 1 Plant Production Department, College of Food and Agricultural Sciences, King Saud University, \\ Riyadh 11451, Saudi Arabia; alqarawi@ksu.edu.sa (A.A.A.); bdar@ksu.edu.sa (B.A.D.); \\ talshahrani@ksu.edu.sa (T.S.A.); mhabib@ksu.edu.sa (M.M.H.); mjaved@ksu.edu.sa (M.M.J.); \\ eabdallah@ksu.edu.sa (E.F.A.) \\ 2 Botany and Microbiology Department, College of Science, King Saud University, Riyadh 11451, Saudi Arabia; \\ habeer@ksu.edu.sa \\ 3 Department of Biology, College of Sciences, Princess Nourah Bint Abdulrahman University, \\ Riyadh 11451, Saudi Arabia; mnalzain@pnu.edu.sa \\ * Correspondence: jmalik@ksu.edu.sa
}

check for updates

Citation: Malik, J.A.; AlQarawi, A.A.; Dar, B.A.; Hashem, A.; Alshahrani, T.S.; AlZain, M.N.; Habib, M.M.; Javed, M.M.; Abd_Allah, E.F. Arbuscular Mycorrhizal Fungi Isolated from Highly Saline "Sabkha Habitat" Soil Alleviated the $\mathrm{NaCl}$-Induced Stress and Improved Lasiurus scindicus Henr. Growth. Agriculture 2022, 12, 337. https:/ / doi.org/10.3390/agriculture12030337 Academic Editors: Ricardo Aroca, Doan Trung Luu, Janusz J. Zwiazek and Gabriela Amodeo

Received: 17 January 2022

Accepted: 25 February 2022

Published: 27 February 2022

Publisher's Note: MDPI stays neutral with regard to jurisdictional claims in published maps and institutional affiliations.

Copyright: (C) 2022 by the authors. Licensee MDPI, Basel, Switzerland. This article is an open access article distributed under the terms and conditions of the Creative Commons Attribution (CC BY) license (https:// creativecommons.org/licenses/by/ $4.0 /)$.

\begin{abstract}
Salt stress is one of the most significant abiotic stresses that substantially negatively impact plant growth and productivity. However, a slew of research thus far has investigated the ameliorating properties of arbuscular mycorrhizal (AM) symbiosis and their potential to improve plant tolerance to salt stress. The present study aimed to evaluate and compare the role of mycorrhizal inocula obtained from Sabkha (S-AMF) and non-Sabkha (NS-AMF) habitats of Saudi Arabia on the morphological, physiological, and biochemical behaviors of the Lasiurus scindicus plant. For this reason, arbuscular mycorrhizal fungi (AMF) isolated from Sabkha and non-Sabkha soils were treated with salinity-exposed L. scindicus. The results revealed that the AMF-treated plants had higher growth metrics and increased synthesis of photosynthetic pigments, which were reduced by salt stress. Furthermore, the application of AM symbiosis induced an increase in the activities of the antioxidant system, which resulted in a reduction of the plant oxidative damage. It was also found that the increased accumulation of proline and phenols acted as a protective measure. Moreover, plants inoculated with S-AMF had the highest ameliorating responses on all the studied parameters compared to NS-AMF. This could be attributed to the presence of habitat-specific AMF, which may have induced adaptive plasticity in plants to tolerate or resist extreme salinity. However, further study in exploring the S-AMF diversity is needed to make it an ecofriendly choice for the restoration of salinity-affected ecosystems.
\end{abstract}

Keywords: arbuscular mycorrhizal fungi (AMF); Sabkha; salinity; restoration; Lasiurus scindicus

\section{Introduction}

Unique saline-beds or saline-plains known as Sabkhas are widely found in Saudi Arabia's dry and semi-arid terrain [1,2], and they range from a few hectares to hundreds of square kilometers. Sabkhas are generally scarce of vegetation and mainly inhabit saltresistant halophytic species, derived through the variation in moisture and salinity [3,4]. Soil salinity (ECe $>4 \mathrm{dSm}^{-1}$ ) is considered one of the most worrying abiotic stresses to plants, especially in arid and semi-arid regions [5]. An approximate estimation suggests that salinity affects more than a billion hectares of land all over the planet and counting [6]. Excessive salt concentrations in the soil result from natural processes and become aggravated (10\%/year) due to anthropogenic practices [5]. By the middle of the 21st century, half of the earth's cultivable land is prone to be engulfed by salinity $[7,8]$. Soil salinity inflicts immense damage to plant functioning and growth by reducing water uptake capacity, damaging root structure, inducing ionic toxicity, and causing osmotic stress [9-13]. Moreover, 
excessive amounts of $\mathrm{Na}^{+}$and $\mathrm{Cl}^{-}$ions in salinity-inflicted soils can blight enzyme and other biological activities, causing ionic leakage from cell membranes and hence their malfunction, and enhancing the inhibition of chlorophyll biosynthetic pathway, thus reducing photosynthesis in plants [14-16]. All the NaCl-induced ruinous effects collectively lead to significant oxidative stress (the production of reactive oxygen species (ROS), such as hydrogen peroxide $\left(\mathrm{H}_{2} \mathrm{O}_{2}\right)$, etc.), resulting in a considerable reduction of plant growth and productivity [17-19].

Over the years, various methods have been developed and adapted to overcome the harmful effects of salinity stress on plants and have received paramount attention. One such method is the application of symbiotic association of arbuscular mycorrhizal fungi (AMF) with the plant roots. AMF belong to the subphylum Glomeromycotina (phylum Mucoromycota) [20], whose survival depend upon the symbiotic association with the plant roots. They acquire the essential carbohydrates and lipids from the plants and in return enhance the uptake of water and nutrients (NPK) in the plants through increased root surface area [21,22]. Additionally, AM symbiosis improves soil quality and increases plant resistance towards biotic and abiotic stresses $[23,24]$. They are naturally found in association with the roots of halophytes in saline habitats and colonize $80 \%$ of the terrestrial plants, with some exceptions from Brassicaceae and Chenopodiaceae [23,25-27]. AMF-Plant interaction has been reported to enhance plant resistance in salt-stressed environments [28-30]. For example, the formation of AM symbiosis boosts the intake capacity of nutrients and water [28,31], increases the accumulation of osmotic regulators, and upregulates the photosynthetic activities under salinity stress [31,32]. AM symbiosis plays a vital role in enhancing enzymes and antioxidant activities in plants, thereby successfully reducing and/or detoxifying ROS [28,31-33].

Lasiurus scindicus Henrard (Poaceae) is a perennial, drought-resilient, and nutritiously valuable forage grass [34-37], naturally found in the dry regions of Africa, Asia, and Saudi Arabia [34,36,38]. This plant plays a vital role in rangeland stabilization [39] and is considered a moderately salt-tolerant species [40]. However, the studies hitherto indicate that increasing salt stress has a negative effect on its growth parameters, such as seed germination, photosynthetic activities, etc. [41-44]. For all the facts, AM symbiosis performs a crucial role in ameliorating the salt-induced stress in plants [28]. To our knowledge, hardly any study has been put forward to investigate the potential effects of AM symbiosis in improving the performance of L. scindicus against salt stress. Moreover, a few studies suggest that using AMF species isolated from saline habitats have given promising results in mitigating the salinity stress compared with those isolated from culture collections $[45,46]$. We hypothesized that: (1) Salinity can negatively affect the growth of L. scindicus plants by altering the physiological and biochemical activities; (2) AMF inoculation will improve the salt tolerance of plants by increasing the photosynthetic activities, the production of proline and phenols, and by enhancing the antioxidant activities; (3) AMF isolated from Sabkha habitats are more adapted to salinity stress and thus their symbiotic association can potentially increase the salt stress ameliorating abilities of plants.

Therefore, the present study aimed to investigate whether the symbiotic association of AMF isolated from highly saline Sabkha habitats can comparatively play a better role in alleviating salinity stress effects on plants than AMF isolated from non-Sabkha habitats. This study will help us understand the role of Sabkha AM symbiosis in helping the desert vegetation adapt to extreme salinity, thus making it an alternate and easy tool for restoring salinity-affected ecosystems.

\section{Materials and Methods}

\subsection{Sampling, AMF Inoculum Production, and Identification}

The soil sampling was conducted from two different habitats of Saudi Arabia, viz.: Sabkha (highly saline) located in Aushazia, AlQasim $\left(26^{\circ} 03^{\prime} 58^{\prime \prime} \mathrm{N} 44^{\circ} 07^{\prime} 55.6^{\prime \prime} \mathrm{E}\right)$ and the non-Sabkha (non-saline) habitat of Thumama $\left(26^{\circ} 08^{\prime} 14.7^{\prime \prime} \mathrm{N} 45^{\circ} 31^{\prime} 00.9^{\prime \prime} \mathrm{E}\right)$, Riyadh, Saudi Arabia. All the soil samples were collected under the rhizosphere of dominant plant species in both habitats. 
The collected soil samples were tested for AMF presence and further propagated in a trapculture with Maize (Zea mays L.) as a target mycotrophic plant. After twelve weeks of maize cultivation in the Sabkha (S-AMF) and non-Sabkha (NS-AMF) soils, AMF spores were scrupulously extracted by using the wet sieving and decanting method [47]. Spores were mounted on slides with a mixture of polyvinyl alcohol-lactic acid-glycerol (PVLG) and Melzer's reagent $(1: 1, v / v)$ [48] for identification via already established literature [49,50]. The guidelines of the International Culture Collection of (vesicular) arbuscular mycorrhizal fungi (INVAM) were also followed. The species found in the Sabkha habitat were identified as Claroideoglomus etunicatum, Funneliformis mosseae, Gigaspora margarita, and Scutellospora calospora (Figure 1A-D). In contrast, Claroideoglomus etunicatum, Funneliformis mosseae, and Gigaspora margarita were found in the non-Sabkha habitat (Figure 1E-G). The inocula from both the habitats consisted of a relevant mixture of all the identified species, including spores, mycelia, and colonized maize roots, and were referred to S-AMF (Sabkha AMF) and NS-AMF (non-Sabkha AMF), respectively (Figure 1). Equal amounts of each inoculum were added to the corresponding pots at sowing time just below L. scindicus seeds. To provide a general microbial population free of AMF propagules, N-AMF (non-AMF)-inoculated plants received the same amount of autoclaved AMF inoculum and filtrate $(<20 \mathrm{~m})$ of the AMF inoculum.

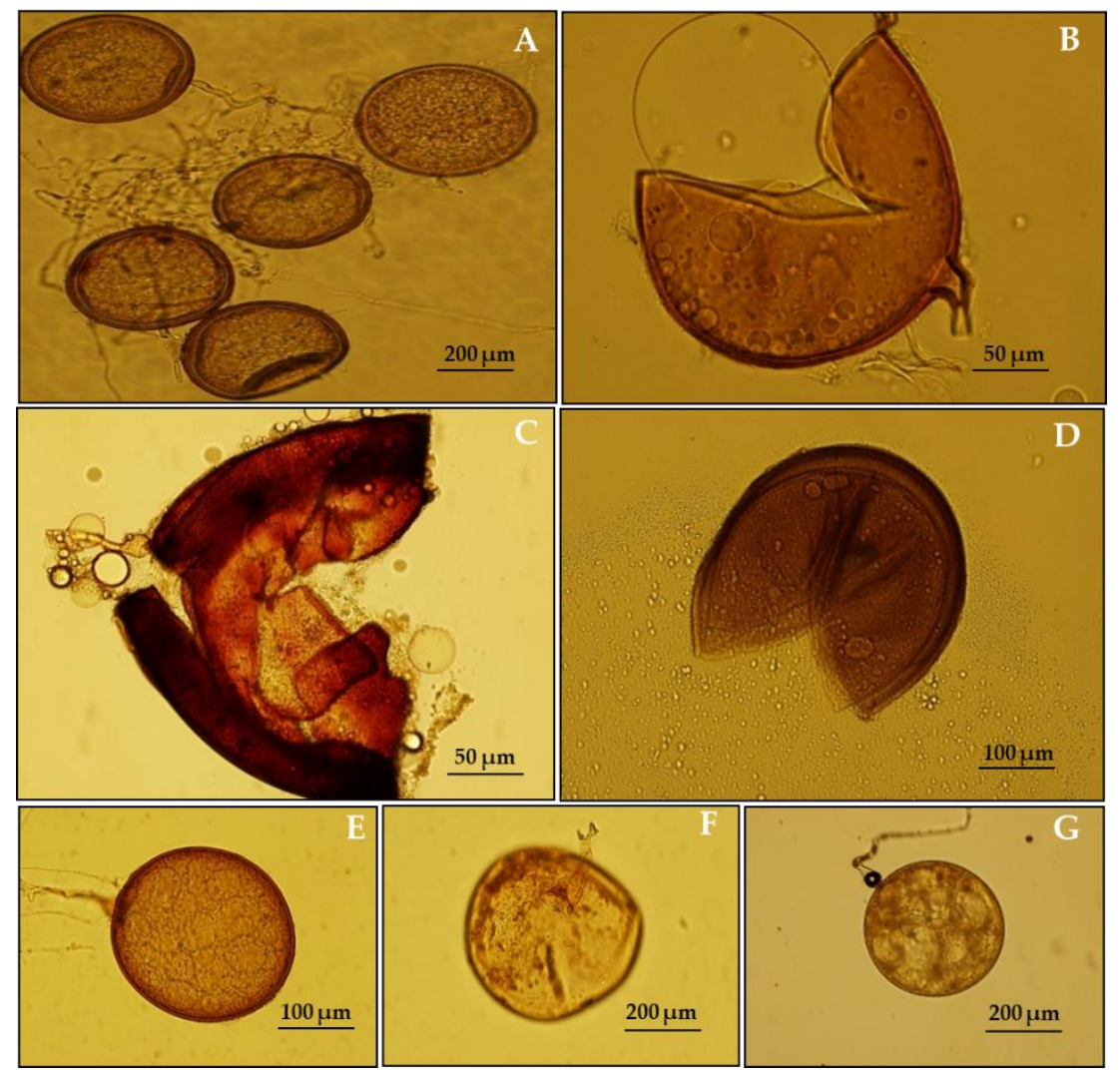

Figure 1. Showing arbuscular mycorrhizal fungi spores collected from the trap culture of Sabkha and non-Sabkha soil. (A-D) Sabkha Spores; (E-G) non-Sabkha spores. (A) intact spores of Claroideoglomus etunicatum; (B) crushed spore of Funneliformis mosseae; (C) crushed spore of Gigaspora margarita; (D) crushed spore of Scutellospora calospora; (E) intact spore of Claroideoglomus etunicatum; (F) intact spore of Funneliformis mosseae; (G) intact spore of Gigaspora margarita.

\subsection{Collection of L. scindicus Seeds and Preparation of Soil Mixture}

Lasiurus scindicus spikes bearing fully mature seeds were collected from the Thumama National Park, Riyadh (250 $\left.{ }^{\prime} 13.7^{\prime \prime} \mathrm{N} 46^{\circ} 36^{\prime} 00.9^{\prime \prime} \mathrm{E}\right)$ and air-dried at room temperature inside the laboratory, then stored until further use. Seeds collected from the dried spikes were surface-sterilized in $5 \%$ sodium hypochloride $(\mathrm{NaClO})$ solution for $3 \mathrm{~min}$. The solution 
was rinsed off by washing seeds twice in distilled and sterilized water. The seed viability (petri experiment) was checked and found to be $>95 \%$. The pots $(14 \mathrm{~cm}$ diameter $\times 13 \mathrm{~cm}$ height $\times 11 \mathrm{~cm}$ bottom) for the experiment were filled with autoclaved sand-soil (1:1 ratio) mixture. Five seeds sown in each pot were thinned to two seedlings once they had been established to avoid competition.

\subsection{Experimental Design}

The pot experiment was conducted under controlled conditions in the growth chamber of the Plant Production Department, King Saud University, Riyadh. The average temperature throughout the experiment was maintained at $35 / 25{ }^{\circ} \mathrm{C}(\mathrm{D} / \mathrm{N})$, light duration of $14 / 10 \mathrm{~h}(\mathrm{~L} / \mathrm{D})$ with relative humidity ranging from 50-60\%. A two-factorial pot experiment in complete randomized design (CRD) was conducted having three inoculation treatments, viz.: (1) non-AMF (N-AMF), (2) non-Sabkha (NS-AMF), and (3) Sabkha (S-AMF), as one factor and three levels of salinity $(0 \mathrm{mM} \mathrm{NaCl}$ (Control), $100 \mathrm{mM} \mathrm{NaCl}$, and $200 \mathrm{mM}$ $\mathrm{NaCl}$ ) taken as another factor. The experiment was repeated three times for all the factors. Therefore, each inoculation treatment had nine replications, and a total of 27 pots were set with two L. scindicus plants grown in each pot. The salinity was applied after one month of the experiment to allow the better establishment of AM colonization and plant growth. Pots were irrigated as and when required to maintain field capacity and salinity levels. Hoagland's solution (without Phosphorous) was applied thrice for the whole period of experimentation.

\subsection{Growth Parameters}

The plants were harvested after three months of the experiment under salt stress. The shoot and root systems of the plants were separated. The morphological measurements such as shoot length and shoot and root biomass were measured before and after ovendrying them for $48 \mathrm{~h}$ at $75^{\circ} \mathrm{C}$. In addition, the total root length (TRL), root surface area (RSA), root diameter (RD), and root volume (RV) were measured by using WinRHIZO software (v5.0, Regent Instruments, Quebec, QC, Canada) for scanned roots.

\subsection{Symbiotic Development and Spore Count}

The fine roots were carefully selected, separated, and washed with distilled water. The cleaned roots were further processed in $10 \% \mathrm{KOH}$ at $80{ }^{\circ} \mathrm{C}$ for $30 \mathrm{~min}$, washed again, and passed through $\mathrm{H}_{2} \mathrm{O}_{2}(3 \%)$ for 3 min before acidified with $1 \% \mathrm{HCl}$ for $10 \mathrm{~min}$ and finally stained in Trypan blue at $80{ }^{\circ} \mathrm{C}$ for a further $20 \mathrm{~min}$ [51].

The stained root segments were mounted on glass slides in a lactoglycerol solution. Twenty stained root segments were mounted on each slide. The coverslip was carefully placed and pressed to investigate different structures present in the root segment under an optical microscope at $400 \times$ magnification. A minimum of 50 root segments from each sample were observed to assess intraradical colonization. The presence of mycelium, vesicles, and arbuscules was recorded. The percentage and intensity of intraradical arbuscular mycorrhizal colonization (mycelium, vesicles, and arbuscular development) within the roots were calculated by following the methods of [52,53]. From the substrate of each treatment, the spores were isolated as per the methods mentioned earlier [47]. The total spore population in each treatment was calculated based on $100 \mathrm{~g}$ dry soil.

\subsection{Chlorophyll Contents and Carotenoids}

Mashing 250-350 mg of leaf sample in $10 \mathrm{~mL} \mathrm{80 \%} \mathrm{acetone} \mathrm{solution} \mathrm{and} \mathrm{centrifuged} \mathrm{at}$ $5000 \mathrm{rpm}$ for $5 \mathrm{~min}$ yielded chlorophyll $a$, chlorophyll $b$, total chlorophyll, and carotenoids $[54,55]$. The samples were then incubated in the dark for three hours before the absorbance was measured at wavelengths 480, 510, 645, and 663. 


\subsection{Estimation of Proline}

Proline $(\mu \mathrm{g} / \mathrm{gFW})$ was estimated by homogenizing $0.5 \mathrm{~g}$ of fresh plant tissue in $10 \mathrm{~mL}$ sulfosalicylic acid (3\%) using mortar and pestle. The homogenate was centrifuged (Benchtop Centrifuge-5810R, Eppendrof, Hamburg, Germany) at $5000 \mathrm{rpm}$ for $10 \mathrm{~min}$, and $2 \mathrm{~mL}$ supernatant was extracted in a separate test tube. The extract $(2 \mathrm{~mL})$ along with glacial acetic acid and ninhydrin $\left(2 \mathrm{~mL}\right.$ each) were incubated for $1 \mathrm{~h}$ in a boiling water bath (at 94-100 ${ }^{\circ} \mathrm{C}$ ) followed by an ice shock. To this, toluene $(4 \mathrm{~mL})$ was added, and the chromophore containing toluene was collected in a separate tube after mixing for $20 \mathrm{~s}$. The absorbance using UV-VIS spectrophotometer (SHIMADZU, Kyoto, Japan, UV1800) was recorded at $520 \mathrm{~nm}$ [56]. A standard curve was obtained using known concentrations of proline.

\subsection{Total Phenolic Content in L. scindicus}

According to Ainsworth's procedure, the total phenolic content of L. scindicus was determined using the Folin-Ciocalteu reagent [57]. The sample extract $(0.5 \mathrm{~mL}$ of $100 \mu \mathrm{g} / \mathrm{mL})$ was combined with $2 \mathrm{~mL}$ Folin-Ciocalteu reagent (diluted 1:10 with de-ionized water) and $4 \mathrm{~mL}$ aqueous $\mathrm{Na}_{2} \mathrm{CO}_{3}(7.5 \% \mathrm{w} / \mathrm{v})$. For thirty minutes, the reaction mixture was incubated at room temperature, and the absorbance was read at $765 \mathrm{~nm}$ using a UV-VIS spectrophotometer (SHIMADZU, Kyoto, Japan, UV1800). The linear equation of a standard curve produced with gallic acid was used to calculate the total phenolic content. The total phenol value was expressed as milligrams of gallic acid equivalents per gram of dry weight (mg GAE/g DW).

\subsection{Determination of Hydrogen Peroxide $\left(\mathrm{H}_{2} \mathrm{O}_{2}\right)$ Content}

The $\mathrm{H}_{2} \mathrm{O}_{2}$ content of plants was determined by following the established procedure of [58]. As per this procedure, the plant material $(500 \mathrm{mg})$ was ground with $5 \mathrm{~mL}$ of $0.1 \%$ $(w / v)$ trichloroacetic acid (TCA) in ice-cold mortar and pestle, followed by centrifugation at $12,000 \times g$ in a (Benchtop Centrifuge-5810R, Eppendorf, Hamburg, Germany) for 20 min, and the supernatant was separated. Subsequently, $0.5 \mathrm{~mL}$ of $10 \mathrm{mM}$ potassium phosphate buffer $(\mathrm{pH} 7.0)$ along with $1 \mathrm{M}$ potassium iodide solution $(1 \mathrm{~mL})$ was added to the extracted supernatant $(0.5 \mathrm{~mL})$, and the absorbance was measured at $390 \mathrm{~nm}$ after $1 \mathrm{~h}$ of dark incubation. The content of $\mathrm{H}_{2} \mathrm{O}_{2}$ was quantified by using a standard curve prepared from the known $\mathrm{H}_{2} \mathrm{O}_{2}$ concentration.

\subsection{Protein Estimation and Antioxidant Enzyme Activity}

The plant material (300 mg) was homogenized with liquid nitrogen and dissolved in $100 \mathrm{mM}$ sodium phosphate buffer (pH 7.4) containing 1\% PVP and 0.5\% (v/v) Triton-X 100. The mixture was then centrifuged for $20 \mathrm{~min}$ at $4{ }^{\circ} \mathrm{C}$ at $20,000 \mathrm{rpm}$. The supernatant was collected and kept at $-20^{\circ} \mathrm{C}$ to determine protein and enzyme activity. Bradford's method was used to determine the total protein [59]. In a nutshell, $100 \mu \mathrm{L}$ of protein extract was combined with $100 \mu \mathrm{L}$ of $\mathrm{diH}_{2} \mathrm{O}$ before being added to $2 \mathrm{~mL}$ of Bradford's reagent. After that, the sample was incubated for $5 \mathrm{~min}$ absorbance was measured at $595 \mathrm{~nm}$. A bovine serum albumin (BSA) standard curve was used to assess the protein level.

\subsubsection{Superoxide-Dismutase (SOD, EC 1.15.1.1)}

The activity was assayed using the method from [60]. The enzyme extract $(100 \mu \mathrm{L})$ was exposed to $0.25 \mathrm{mM}$ pyrogallol $(1 \mathrm{~mL})$ and $0.1 \mathrm{M}$ sodium phosphate buffer $(1.9 \mathrm{~mL}, \mathrm{pH} 7.4)$. The absorbance at $420 \mathrm{~nm}$ of the reaction mixture was measured in a spectrophotometer. The SOD activity was calculated as the quantity of enzyme required to inhibit pyrogallol oxidation by $50 \%$, represented as $\mathrm{U} / \mathrm{mg}$ of protein.

\subsubsection{The Catalase (CAT, EC 1.11.1.6)}

The activity was estimated spectrophotometrically according to [61]. A volume of $0.5 \mathrm{~mL} \mathrm{H}_{2} \mathrm{O}_{2}(75 \mathrm{mM}), 1.5 \mathrm{~mL}$ buffer (phosphate $0.1 \mathrm{M}, \mathrm{pH}$ ), and enzyme extract ( $50 \mathrm{~mL}$, diluted) were combined to make the reaction mixture. The decrease in absorbance was 
measured by monitoring the decomposition of $\mathrm{H}_{2} \mathrm{O}_{2}$ for $2 \mathrm{~min}$ at $240 \mathrm{~nm}$. The CAT activity was expressed as $\mathrm{U} / \mathrm{mg}$ of protein.

\subsubsection{Ascorbate-Peroxidase (APX, EC 1.11.1.11)}

The activity was carried out according to [62] and expressed as $\mathrm{U} / \mathrm{mg}$ of protein. The reaction medium was as follows: $0.1 \mathrm{M}$ sodium phosphate buffer $(1 \mathrm{~mL}, \mathrm{pH} 7.4), 1 \mathrm{~mL}$ distilled water, $100 \mu \mathrm{L}$ ETDA $(0.1 \mathrm{mM})$, hydrogen peroxide $(100 \mu \mathrm{L})$, and an enzyme extract $(100 \mu \mathrm{L})$. The absorbance was recorded at $290 \mathrm{~nm}$ with a spectrophotometer.

\subsubsection{Glutathione-Reductase (G.R., EC 1.6.4.2)}

The activity was measured according to the method of [63]. The reaction mixture consisted of $0.15 \mathrm{mM} \mathrm{NADPH}(950 \mu \mathrm{L}), 0.5 \mathrm{mM}$ glutathione, $3 \mathrm{mM} \mathrm{MgCl} 2$ in $50 \mathrm{mM}$ Tris (pH 7.5) and $50 \mu \mathrm{L}$ enzyme extract. The glutathione-dependent oxidation of NADPH was spectrophotometrically measured at $340 \mathrm{~nm}$, expressed as $\mathrm{U} / \mathrm{mg}$ of protein.

\subsubsection{Monodehydroascorbate-Reductase (MDHAR, EC 1.6.5.4)}

The activity was determined by following the method of [64], where the protein extract was mixed with $\mathrm{NADH}$, ascorbate, and an excess of ascorbate oxidase to create monodehydroascorbate and NADH oxidation. For $5 \mathrm{~min}$ at room temperature, the protein extract $(15 \mu \mathrm{L})$ was incubated with reaction buffer $(85 \mu \mathrm{L})$ containing potassium phosphate (0.1 M pH 7.5), NADH ( $0.25 \mathrm{mM}$, $) 1.5 \mathrm{mM}$ ascorbate, and ascorbate oxidase (0.02 U). The absorbance was measured spectrophotometrically after every $30 \mathrm{~s}$, and MDHAR activity was expressed by monitoring the oxidation of NADH at $340 \mathrm{~nm}$.

\subsection{Statistical Analysis}

The data were statistically analyzed using SAS ${ }^{\circledR} 9.2$ Software. A two-way factorial (levels of salinity $\times$ different types of AMF) was used to determine if AMF symbiosis influenced different tolerance levels of salinity stress. Tukey (Tukey's honestly significant difference (HSD)) tests $(p=0.05)$ were used to compare the effects among treatment means when interactions between salinity levels and different types of AMF were significant.

\section{Results}

\subsection{Effect of Salinity Stress on AMF Colonization of L. scindicus Plants and Total Spore Count}

After four months of cultivation under salt stress, a microscopic study of the mycorrhizal status of L. scindicus plants indicated the presence of all the predicted AMF structures (mycelium, vesicles, arbuscules, and spores) in roots (Figure 2). The analysis of the mycorrhizal colonization showed that all the parameters (mycelium, vesicles, and arbuscules) decreased with the increasing salinity stress in S-AMF- and NS-AMF-inoculated plants (Figure 2, Table S1). However, plants inoculated with S-AMF revealed a higher colonization percentage at both the salinity levels of $100 \mathrm{mM}(\mathrm{Myc}=75.56 \%$; $\mathrm{Ves}=62.22 \% ; \mathrm{Ar}=75.56 \%)$ and $200 \mathrm{mM}(\mathrm{Myc}=28.89 \%$; Ves $=20 \% ; \mathrm{Ar}=24.44 \%$ ) compared to the plants inoculated with NS-AMF. The highest colonization percentage was recorded in non-stressed S-AMFinoculated plants. The total spore count showed an increase at $100 \mathrm{mM} \mathrm{NaCl}$ stress in both S-AMF- and NS-AMF-inoculated L. scindicus plants (Table 1). A drastic decline in spore production was recorded at a salinity level of $200 \mathrm{mM}$, where S-AMF-inoculated plants showed significantly higher spore count (76/100 g soil). 


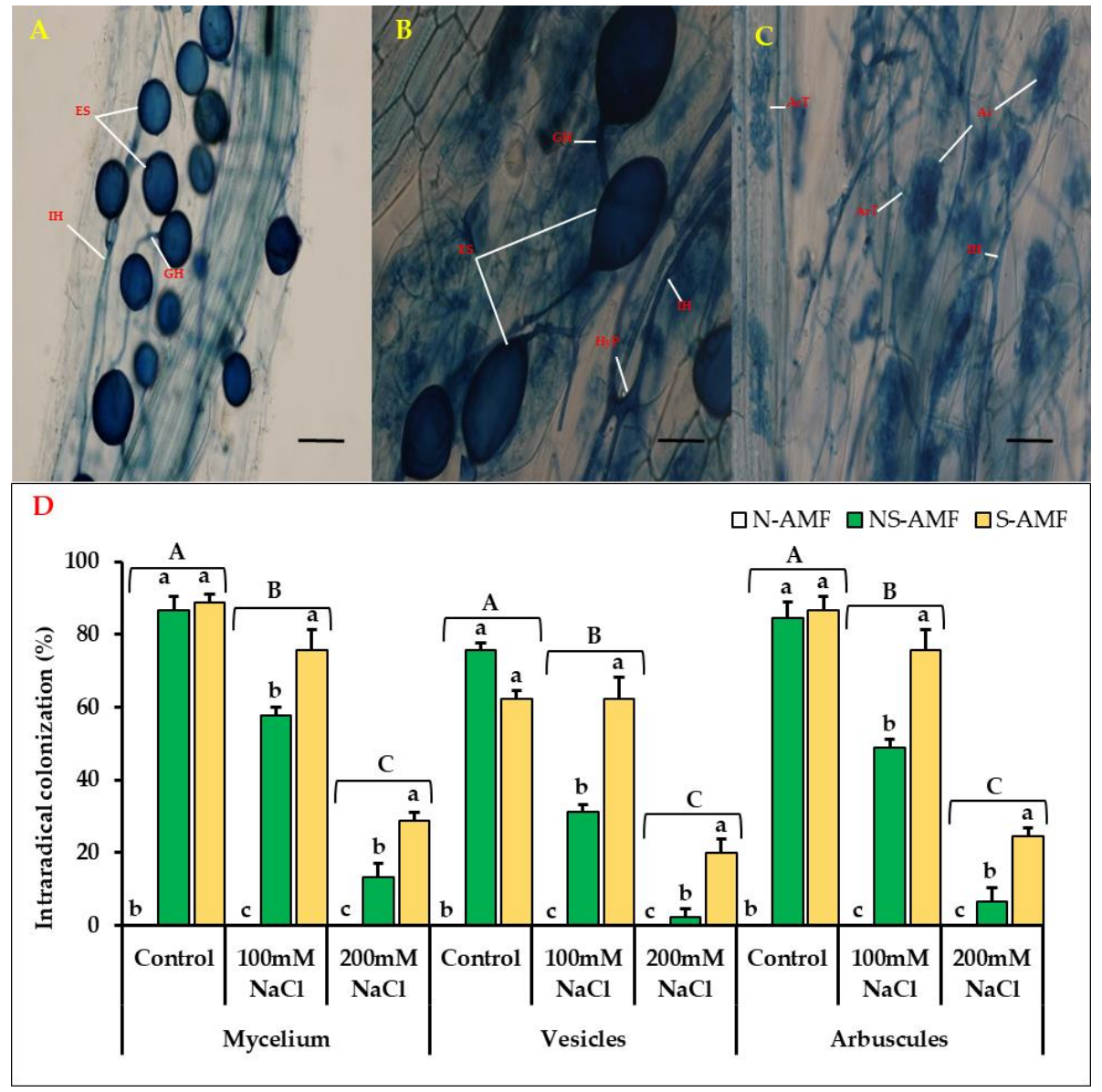

Figure 2. Showing photomicrographs indicating the perfect abundance of arbuscular mycorrhizal colonization in the roots of L. scindicus plants cultivated under salt stress. (A-C) the presence of hyphopodium (HyP) indicated AMF colonization, which later propagated and developed various structural forms. Extraradical intact spores (ES); intercellular hyphae (IH); germinating hyphae (GH); arbuscular trunk (ArT); arbuscules (Ar). (D) salt stress on the root colonization of L. scindicus plants inoculated with S-AMF and NS-AMF. Capital letters indicate the significance of the salinity effect, while small letters indicate AM symbiosis status at $p=0.05$ (Tukey's HSD test).

Table 1. Effect of Salt stress on the spore count of Sabkha and non-Sabkha AMF.

\begin{tabular}{ccc}
\hline Treatment & Status & Spores/100 g Dry Soil \\
\hline \multirow{2}{*}{ Control } & N-AMF & 0.00 \\
& NS-AMF & $211 \pm 14.799 \mathrm{~B}, \mathrm{a}$ \\
& S-AMF & $196.7 \pm 14.495^{\mathrm{B}, \mathrm{a}}$ \\
\hline \multirow{2}{*}{$100 \mathrm{mM} \mathrm{NaCl}$} & N-AMF & 0.00 \\
& NS-AMF & $292 \pm 8.622^{\mathrm{A}, \mathrm{a}}$ \\
& S-AMF & $282.7 \pm 11.865^{\mathrm{A}, \mathrm{a}}$ \\
\hline & $\mathrm{N}-\mathrm{AMF}$ & 0.00 \\
& NS-AMF & $35.3 \pm 4.096^{\mathrm{C}, \mathrm{b}}$ \\
& S-AMF & $76 \pm 7.371^{\mathrm{C}, \mathrm{a}}$ \\
\hline
\end{tabular}

The first line indicates mean value and the second line indicates \pm SE. Capital letters indicate the significance of the salinity effect, while small letters indicate the effect of AMF at $p=0.05$ (Tukey's HSD test).

3.2. Growth Parameters of S-AMF- and NS-AMF-Inoculated L. scindicus Plants under Different Levels of $\mathrm{NaCl}$ Stress

The application of salt stress showed deleterious impacts on various morphological parameters of L. scindicus (Table S1). When compared to non-inoculated (N-AMF) plants, 
inoculated plants (S-AMF and NS-AMF) considerably improved the growth of L. scindicus cultivated at varying salt concentrations (Figures 3 and 4). The plants growing under salt stress had considerably lower shoot biomass (Figure 3A) and shoot length (Figure 3C) than plants growing under normal conditions. At both salinity levels, the application of AMF-inoculants from Sabkha and non-Sabkha habitats showed no significance but resulted in a slight increase in both parameters. Compared to N-AMF- and NS-AMF-inoculated treatments, plants inoculated with S-AMF demonstrated a comparatively larger shoot length at $200 \mathrm{mM}$ salinity (Figure 3A). In addition, shoot biomass showed a similar pattern for the same comparison.
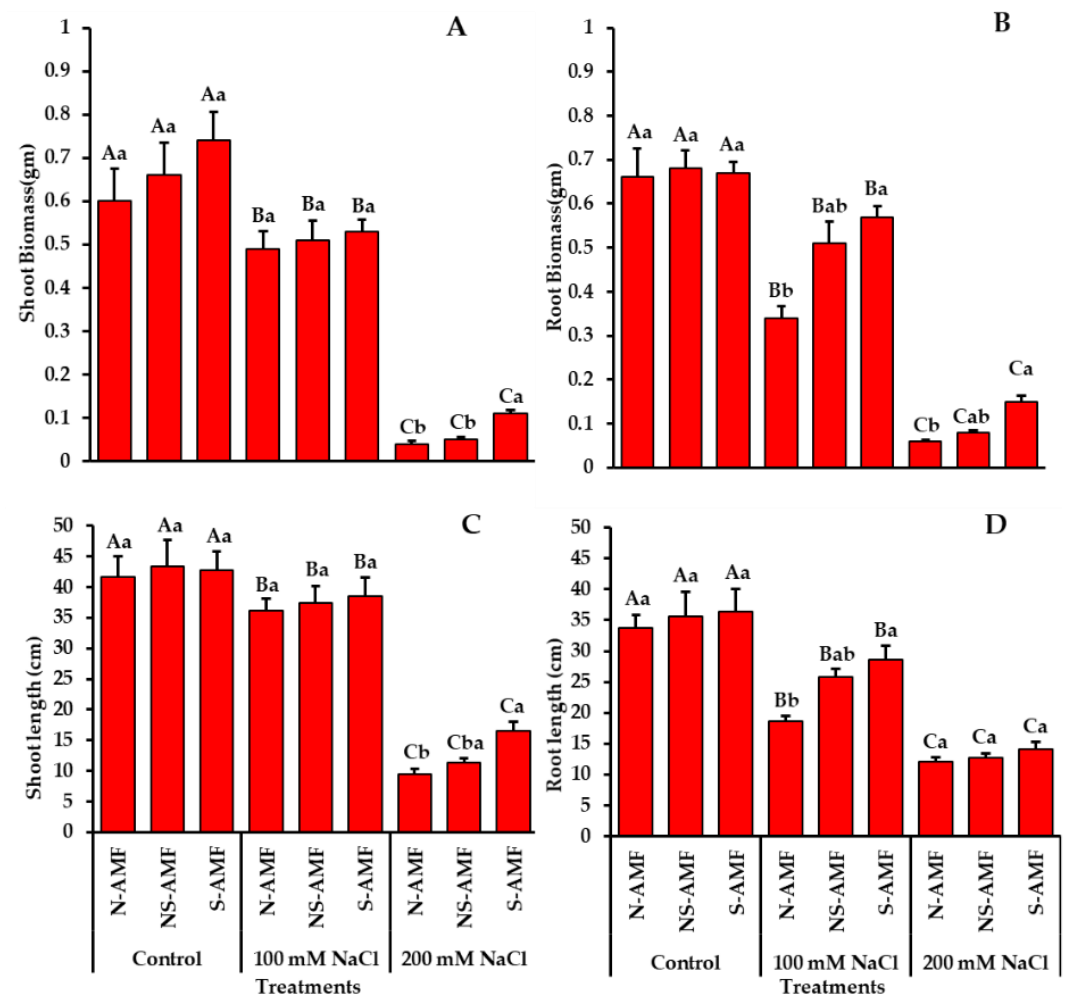

Figure 3. Showing the effect of AM symbiosis (S-AMF and NS-AMF) on the growth parameters such as shoot biomass (A), root biomass (B), shoot length (C), and root length (D) of L. scindicus plants cultivated under different salinity levels. Capital letters indicate the significance of the salinity effect, while small letters indicate the effect of AM symbiosis at $p=0.05$ (Tukey's HSD test).

Under salinity stress, plants had considerably lower root length (Figure 3D), root biomass (Figure 3B), and total root length (Figure 4A). Similarly, the root diameter (Figure 4A), root surface area (Figure 4C), and root volume (Figure 4D) of plants grown under salinity stress were less significant compared to unstressed plants. The symbiotic association of S-AMF and NS-AMF with L. scindicus plants generally showed no significant effect on most of the root parameters at both salinity levels. Still, it did result in a minor rise in all the studied root parameters (Figures 3D and 4A-D). However, the total root length of S-AMF-inoculated plants showed a considerable increase at salinity level $200 \mathrm{mM}$ compared to its counterpart. In addition, the root biomass and root length of both S-AMF- and NS-AMF-inoculated plants showed a significant increase at $100 \mathrm{mM} \mathrm{NaCl}$ stress, while no significant difference was recorded at control and $200 \mathrm{mM}$ salt stress. The rest of the root indices showed the same pattern except for the root surface area, which showed no significance for all salinity levels. 

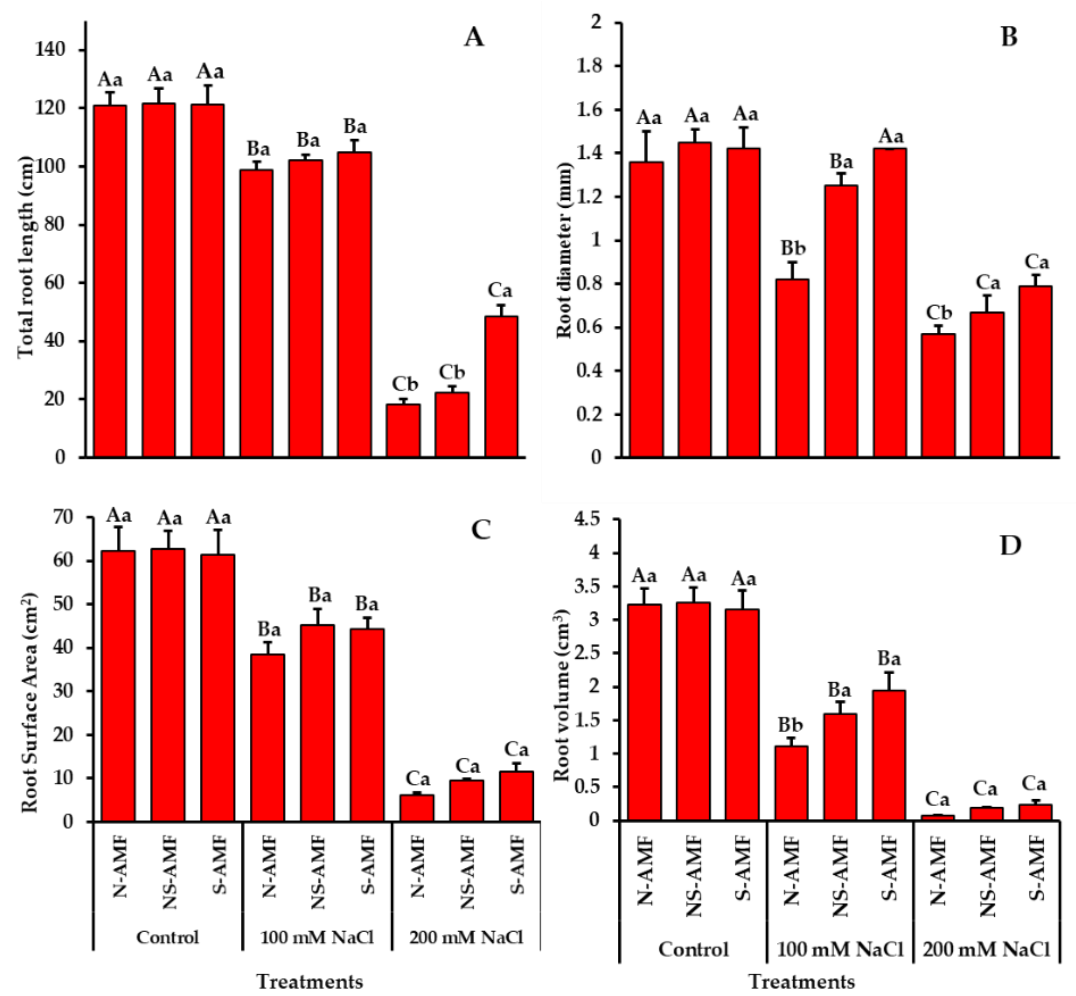

Figure 4. Effect of AM symbiosis (S-AMF and NS-AMF) on growth parameters such as total root length (A), root diameter (B), root surface area (C), and root volume (D) of L. scindicus plants cultivated under different salinity levels. Capital letters indicate the significance of the salinity effect, while small letters indicate the effect of AM symbiosis at $p=0.05$ (Tukey's HSD test).

\subsection{Chlorophyll and Carotenoid Contents of L. scindicus}

The salinity-stressed $L$. scindicus plants showed a significant decline in the concentrations of chlorophyll $a$, chlorophyll $b$, total chlorophyll, and carotenoid pigments (Figure 5A-D). S-AMF and NS-AMF colonization counterbalanced the harmful effects of salt stress and increased the pigment synthesis of chlorophyll and carotenoids. The most significant increase in photosynthetic pigment contents among the salt-stressed plants were recorded in L. scindicus plants inoculated with S-AMF. For example, at $200 \mathrm{mM} \mathrm{NaCl}$ stress, S-AMF-inoculated L. scindicus plants had higher levels of chlorophyll $a(17.9 \%)$, chlorophyll $b(20.8 \%)$, total chlorophyll (20.7\%), and carotenoids (13.4\%) than NS-AMF-inoculated and non-inoculated plants.

\subsection{Proline and Total Phenol Contents}

The results of the salt stress on proline and total phenol of S-AMF- and NS-AMFinoculated L. scindicus plants are shown in (Figure 6A, B). The proline concentration was increased significantly at a salinity stress level of $100 \mathrm{mM}$ but showed a drastic decline at higher stress $(200 \mathrm{mM} \mathrm{NaCl})$. At $100 \mathrm{mM} \mathrm{NaCl}$ stress, the application of AMF isolates enhanced the proline concentration by $40.90 \%$ for S-AMF-inoculated plants and $33.89 \%$ for NS-AMF-inoculated plants. However, at the maximum saline condition $(200 \mathrm{mM}$ $\mathrm{NaCl}$ ), the highest proline concentration was recorded for S-AMF plants. In contrast, NS-AMF plants showed no change when compared to non-inoculated plants (Figure 6A). Total phenol synthesis in plants was exposed to salt stress and different AMF treatments followed a similar pattern (Figure 6B). The addition of $\mathrm{NaCl}(100 \mathrm{mM})$ induced a significant increase in total phenol content, which was further enhanced via S-AMF $(41.27 \%)$ and NS-AMF (34.58\%) inoculation. However, at the highest salinity stress $(200 \mathrm{mM} \mathrm{NaCl})$, NS-AMF-inoculated L. scindicus had the lowest phenol content. 

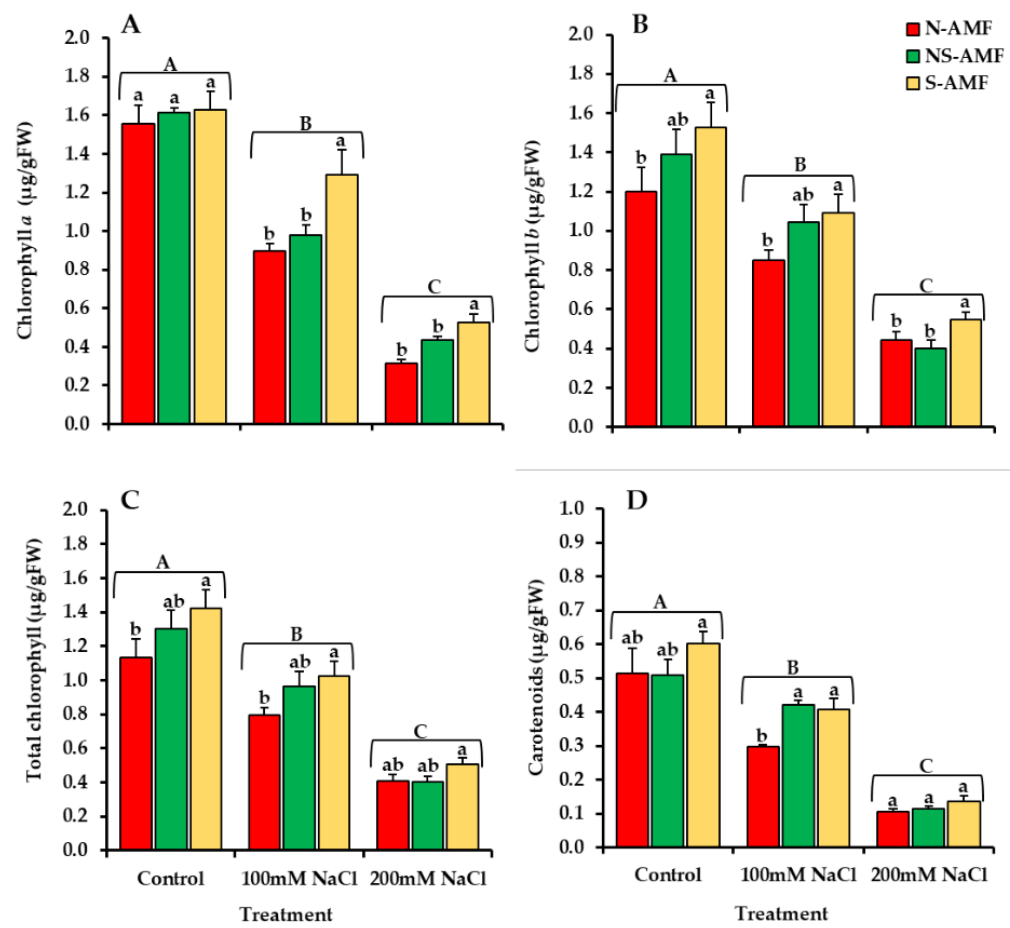

Figure 5. Effect of AM symbiosis (S-AMF and NS-AMF) on chlorophyll $a$ ( $\mu \mathrm{g} / \mathrm{gFW})$ (A), chlorophyll $b$ $(\mu \mathrm{g} / \mathrm{gFW})(\mathbf{B})$, total Chlorophyll $(\mu \mathrm{g} / \mathrm{gFW})(\mathbf{C})$, and carotenoid $(\mu / \mathrm{gFW})(\mathbf{D})$ synthesis of L. scindicus plants grown under salinity stress $(0,100,200 \mathrm{mM} \mathrm{NaCl})$. Capital letters indicate the significance of the salinity effect, while small letters indicate the effect of AM symbiosis at $p=0.05$ (Tukey's HSD test).
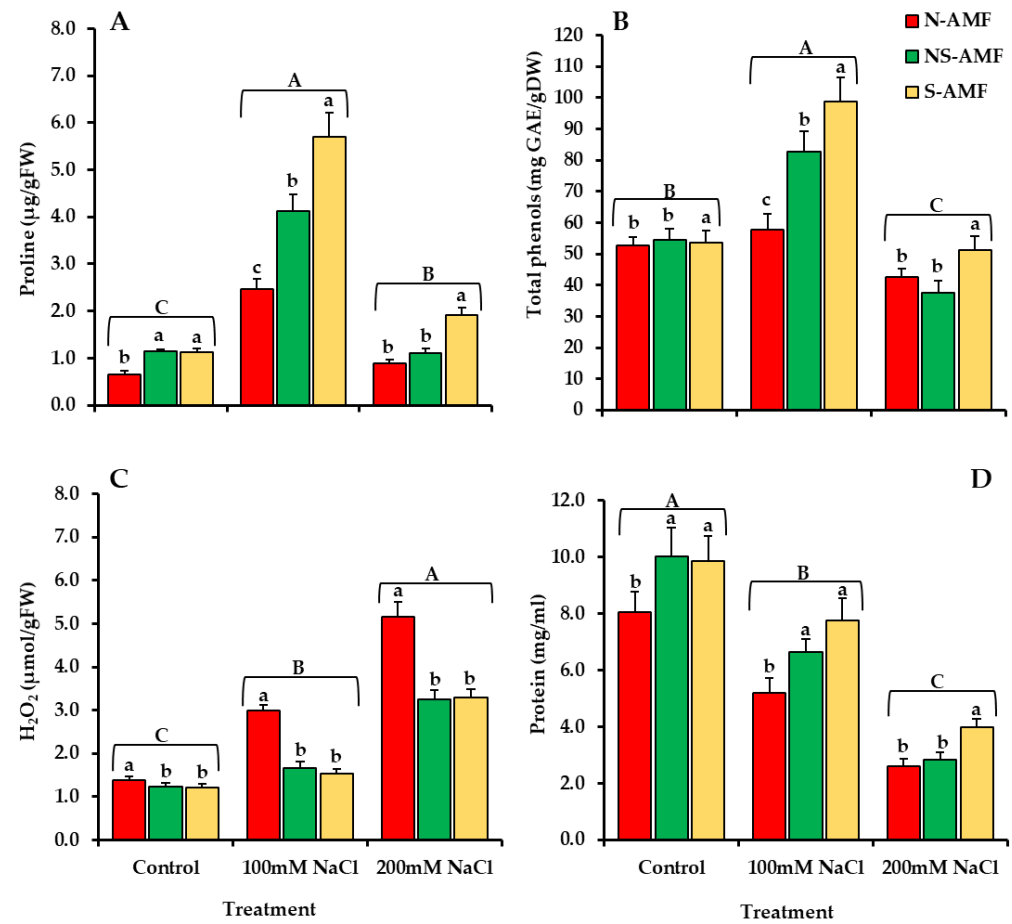

Figure 6. Influence of AM symbiosis (S-AMF and NS-AMF) on the proline (ug/gFW) (A), total phenols (mg GAE/gDW) (B), hydrogen peroxide $\left(\mathrm{H}_{2} \mathrm{O}_{2} \mathrm{umol} / \mathrm{gFW}\right)(\mathbf{C})$, and protein $(\mathrm{mg} / \mathrm{gFW})(\mathbf{D})$ contents of L. scindicus plants under different levels of salinity. Capital letters indicate the significance of the salinity effect, while small letters indicate the effect of AM symbiosis at $p=0.05$ (Tukey's HSD test). 


\subsection{Hydrogen Peroxide $\left(\mathrm{H}_{2} \mathrm{O}_{2}\right)$ Content}

The results showed $\mathrm{H}_{2} \mathrm{O}_{2}$ content increased sharply with increasing salinity levels (Figure 6C). For example, the non-inoculated L. scindicus plants at $200 \mathrm{mM} \mathrm{NaCl}$ stress showed the highest increase. However, the addition of S-AMF and NS-AMF resulted in a significant decrease in $\mathrm{H}_{2} \mathrm{O}_{2}$.

\subsection{Protein Content and Antioxidant Enzyme Activity}

According to the results shown in Figure $6 \mathrm{D}$, there was a significant difference in the protein content of $L$. scindicus plants treated with different concentrations of $\mathrm{NaCl}$ and amended with S-AMF and NS-AMF. When compared to non-stressed plants, salinity supply had a negative effect on protein content, with the lowest recorded in N-AMF-inoculated plants under $200 \mathrm{mM} \mathrm{NaCl}$ stress. At all salinity levels, AMF inoculation caused an increase in protein content. L. scindicus plants inoculated with S-AMF had the highest increase in protein content compared to plants inoculated with NS-AMF and N-AMF.

Antioxidant enzyme activity varied significantly in L. scindicus plants inoculated with AMF under $\mathrm{NaCl}$ stress of $100 \mathrm{mM}$ and $200 \mathrm{mM}$, as seen in Figure 7A-E. At a salinity level of $100 \mathrm{mM}$, L. scindicus plants demonstrated higher SOD, CAT, APX, GR, and MDHAR activity than non-stressed plants, which was further enhanced by AMF inoculation. However, at the highest salinity stress of $200 \mathrm{mM}$, antioxidant activity decreased abruptly. Plants inoculated with S-AMF have produced significantly higher levels of SOD, CAT, APX, GR, and MDHAR, particularly at salinity levels of $100 \mathrm{mM}$.
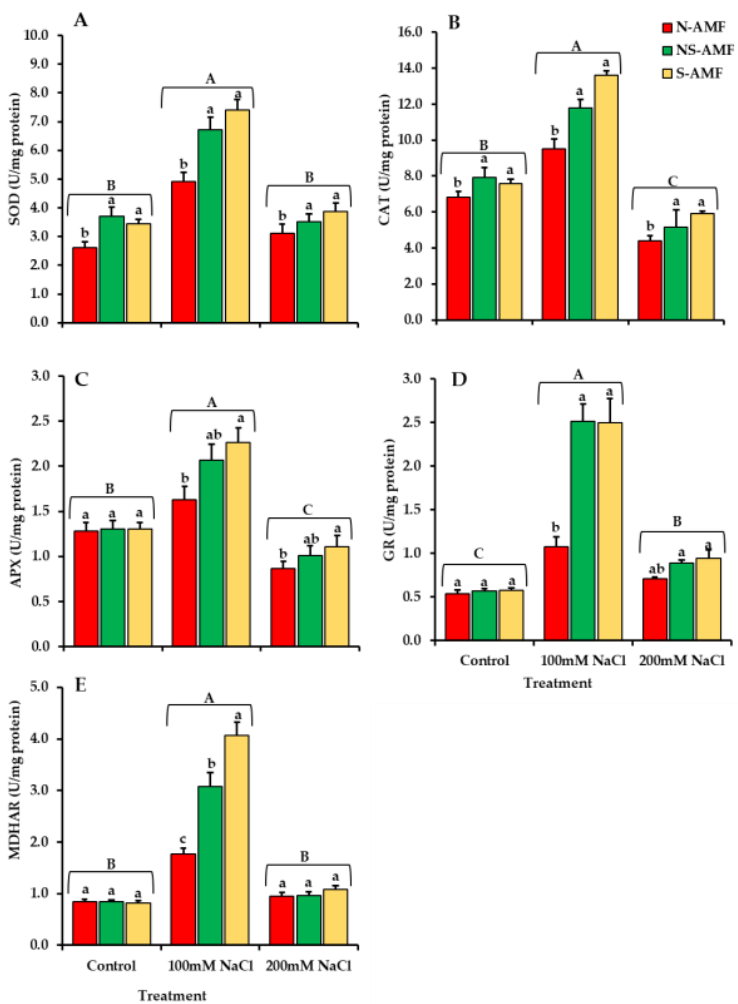

Figure 7. Influence of AM symbiosis (S-AMF and NS-AMF) on $\mathrm{SOD}$ (U/mg protein) (A), CAT (U/mg protein) (B), APX (U/mg protein) (C), GR (U/mg protein) (D), and MDHAR (U/mg protein) (E) activities of $L$. scindicus plants grown under different salinity stress levels. Capital letters indicate the significance of the salinity effect, while small letters indicate the effect of AM symbiosis at $p=0.05$ (Tukey's HSD test).

\section{Discussion}

Soil salinity is one of the critical issues that retards plant growth, resulting in a significant loss of plant production and thus necessitating better management for long-term production $[9,12,16,18]$. Although L. scindicus is somewhat salt-tolerant, previous works 
have shown that salt restriction has deleterious effects on the seed germination, photosynthetic activities, and growth of L. scindicus [41-43]. AM symbiosis play an important role in the growth and tolerance improvement of plants grown in salinity-restricted environments, as reported earlier $[28,30,65]$. Therefore, the present study was conducted to assess and compare the impact of mycorrhizal inocula acquired from Sabkha and non-Sabkha environments on the morphological, physiological, and biochemical properties of L. scindicus plants grown under various saline stress levels. As shown in the results, salinity negatively affected all the root colonization structures such as mycelium, vesicles, and arbuscules. The sporulation of both S-AMF and NS-AMF was also reduced at the highest salinity. This corresponds to the previous research, which found that salinity impeded the germination of AMF spores, slowed extraradical hyphal elongation after colonization, and reduced the quantity of vesicles and arbuscules due to the fact that higher salinity levels have an inhibitory effect on root colonization and thus sporulation [23,24,30,66-68]. In contrast, spore production in the roots of L. scindicus inoculated with S-AMF and NS-AMF increased significantly at moderate salinity levels ( $\mathrm{NaCl}: 100 \mathrm{mM})$, which was in agreement with [69], wherein it was reported that increasing salinity levels stimulate AMF's spore-generating capabilities. However, according to our findings, AMF isolated from Sabkhas increased the growth characteristics of L. scindicus plants cultivated under $\mathrm{NaCl}$ stress, but AMF isolated from non-Sabkha habitats had a weaker alleviating impact. As a result, our findings are consistent with those of $[45,68]$, where the authors stated that inoculating key crops, such as maize and soybean, with AMF isolated from saline regions or pre-treated with salinity conferred a higher salinity resistance and showed improved growth parameters than plants inoculated with a model AMF strain.

The most prevalent morphological response to salt stress is growth suppression [13]. In the current research, the L. scindicus growth parameters such as shoot length, root length, shoot, root biomass, total root length, root surface area, root diameter, and root volume were negatively affected by the presence of high salinity stress in soil. On the other hand, the inclusion of S-AMF and NS-AMF caused an increase in most of these parameters, as evidenced in the previous investigations [70]. AM symbiosis-induced plant development has been linked in part to increased $\mathrm{P}$ feeding, enhanced water uptake from the soil, and increased osmotic potential of soil mediated by mycorrhizal fungi [70,71]. In this study, L. scindicus plants inoculated with S-AMF (an AMF obtained from very salty habitats known as Sabkhas) provided comparatively better results (Figures 3 and 4). This could be because $\mathrm{S}-\mathrm{AMF}$ became more accustomed to greater salt levels, as described in previous investigations $[45,46,68]$.

Many studies have reported a significant drop in chlorophyll and carotenoid concentrations when plants are exposed to salt, and varied perspectives on the impact of salinity on these photosynthetic pigment contents have been reported [72-74]. The loss of chlorophyll in salt-stressed plants has long been assumed to be a marker of oxidative stress that occurs during chlorophyll production. The salt stress damages chloroplasts and increases the activity of chlorophyll-degrading enzymes such as chlorophyllase $[74,75]$. In our study, under both saline and non-saline situations, AMF application from both Sabkha and non-Sabkha sources increased chlorophyll pigment content. Many studies have confirmed that AM symbiosis has a considerable ability to reduce the impacts of salt stress on plant growth by enhancing the photosynthetic activity of plants [31]. The findings were based on the fact that AM symbiosis may boost not only the intake of the nutritional element $\mathrm{Mg}$, but also release hormonal signals that stimulate chloroplast formation [46,76]. The S-AMF-inoculated L. scindicus plants showed the highest levels of chlorophyll and carotenoids, implying a faster rate of photosynthetic activity and growth.

Proline is one of the compatible osmolytes that mediates osmotic adjustment in plants, and its accumulation is regarded as an adaptive measure of stress in plants exposed to salinity [77]. Proline accumulation under salt stress helps stabilize membrane lipids, proteins, and other cellular structures, maintain cell turgor through osmotic adjustment, protect plants against free radical damage, and maintain optimal NADP+/NADPH ratios [31,78]. 
In the current study, salt stress caused proline buildup in L. scindicus plants, which was further enhanced by AMF symbiosis. The increase was most significant in S-AMF plants, particularly when they were exposed to a salinity level of $100 \mathrm{mM}$. This indicated that the higher levels of salinity-induced ROS production were detoxified by the over accumulation of proline in the AMF-colonized L. scindicus plants. Our findings were consistent with those of [31,70], who found higher proline accumulation in Cucumis sativus L. and Ephedra aphylla Forssk plants under AMF treatment. The same results were also reported by [68].

Furthermore, salt stress caused an increase in the concentration of total phenolic compounds in L. scindicus plants. These findings were consistent with previous studies $[79,80]$. The inoculation of S-AMF and NS-AMF to L. scindicus plants increased the total phenolic compound production even more, especially at moderate salinity. These results are linked with the findings of [70]. Plants inoculated with S-AMF had the maximum phenolic accumulation. Increased phenolic compound accumulation improves plant tolerance to salinity constraints through increasing antioxidant capacity. Phenols are good oxygen radical scavengers as their electron reduction potential is lower than that of oxygen radicals, and phenoxyl radicals are generally less reactive than oxygen radicals [81]. As a result, phenolic compounds can scavenge reactive oxygen intermediates while preventing the initiation of subsequent oxidative processes. Therefore, S-AMF-treated L. scindicus plants with higher accumulations of proline and total phenol under higher salinity stress could be more resistant than N-AMF- and NS-AMF-inoculated plants.

Moreover, in this study, high salinity induced an increase in $\mathrm{H}_{2} \mathrm{O}_{2}$ production in L. scindicus. These results were in accordance with the earlier findings on melon landraces [82] and date palm [83]. Hydrogen peroxide $\left(\mathrm{H}_{2} \mathrm{O}_{2}\right)$, a reactive oxygen species (ROS), is produced under a salinity constraint, which could lead to oxidative stress [84]. Damage to key cell components, such as proteins, nucleic acids, and lipids, occurs due to oxidative stress. Therefore, the biomembranes' selective permeability changes, resulting in membrane leakage and changes in the activity of enzymes linked to the membrane [85]. However, the application of AMF from both saline (Sabkha) and non-saline sources caused a significant decrease in the $\mathrm{H}_{2} \mathrm{O}_{2}$ content of L. scindicus grown under $\mathrm{NaCl}$ constraint. The substantial increase in ROS-detoxification enzymes in the plants inoculated by AMF under salinity constraint was most likely responsible for reducing $\mathrm{H}_{2} \mathrm{O}_{2}$ production [31]. Increasing salinity negatively affected the protein content but its production was ameliorated by the inoculation of AMF [86].

Plants up-regulate the intriguing antioxidant defense system, neutralize ROS, and prevent oxidative damage to cells. The antioxidant enzyme activities (SOD, CAT, APX, GR, and MDHAR) of $L$. scindicus were significantly increased at moderate salinity $\mathrm{NaCl}$ stress $(100 \mathrm{mM})$. These activities were further boosted in AMF-treated L. scindicus, particularly those cultivated with the S-AMF inoculants. Similar findings have been observed in other plant species $[31,46,70,87]$. SOD is one of the first defensive enzymes, allowing superoxide radicals to be scavenged and converted to $\mathrm{H}_{2} \mathrm{O}_{2}$, which is then eliminated by CAT or APX and GR in the ascorbate-glutathione cycle (AGC). Ascorbate-peroxidase (APX) reduces $\mathrm{H}_{2} \mathrm{O}_{2}$ by oxidizing water-soluble ascorbate (AsA) to the monodehydroascorbate (MDHA) radical, which is then reduced to AsA by $\mathrm{NAD}(\mathrm{P}) \mathrm{H}$-dependent monodehydroascorbate reductase (MDHAR) [31,88]. In the present study, AMF generally improved the antioxidant activities of $L$. scindicus against the ROS stress induced by $\mathrm{NaCl}$. However, all these enzymes showed their best ameliorating tendencies in S-AMF-inoculated L. scindicus plants.

AMF populations have a greater ability to adapt to varying environmental situations. When biotic and abiotic restrictions grow particularly severe, however, only a few fungal strains can withstand the pressure and become endemic resources. As a result, their importance as biofertilizers for promoting soil fertility and plant growth in the soils influenced by anthropogenic causes and global change is well understood [46]. 


\section{Conclusions}

In conclusion, this study demonstrates that the physiological and biochemical characteristics of L. scindicus exposed to salt stress were significantly reduced. Salinity caused oxidative damage, which resulted in membrane dysfunction. The application of AMF from both Sabkha and non-Sabkha habitats, on the other hand, contributed to the amelioration of salt stress in L. scindicus and improved its growth, biomass, and root activity characteristics. Furthermore, AMF symbiosis boosted physiological and biochemical markers and antioxidant enzyme production. However, AMF acquired from the Sabkha habitat confers more salinity tolerance to L. scindicus plants than AMF isolated from non-Sabkha habitats. Our findings reveal that S-AMF-inoculated L. scindicus plants were more resistant to salinity-induced damage and had a better tolerance for it. As a result of this research, we can see how AMF from Sabkha habitats could be used to generate effective inocula for the successful restoration of salinity-affected and disturbed habitats.

Supplementary Materials: The following supporting information can be downloaded at: https: / / www.mdpi.com/article/10.3390/agriculture12030337/s1, Table S1: Analysis of Variance (ANOVA) on the effects of arbuscular mycorrhizal fungi (AMF) from Sabkha and non-Sabkha habitats on the growth parameters of $L$. scindicus plants grown under different levels of salinity $(S)$.

Author Contributions: Conceptualization, A.A.A. and J.A.M.; data curation, J.A.M. and B.A.D.; formal analysis, B.A.D. and J.A.M.; investigation, A.A.A., J.A.M., A.H., B.A.D. and M.M.H.; methodology, J.A.M., B.A.D. and M.M.H.; project administration, A.A.A.; software, B.A.D., J.A.M. and T.S.A.; supervision, A.A.A. and A.H.; visualization, J.A.M., B.A.D. and M.M.H.; writing —original draft preparation, J.A.M. and B.A.D.; writing—review and editing, A.A.A., J.A.M., B.A.D., A.H., T.S.A., M.M.H., M.N.A., M.M.J. and E.F.A. All authors have read and agreed to the published version of the manuscript.

Funding: Deanship of scientific research in King Saud University for funding and supporting this research through the initiative of DSR Graduate Students Research Support (GSR).

Institutional Review Board Statement: Not applicable.

Informed Consent Statement: Not applicable.

Data Availability Statement: Not applicable.

Acknowledgments: The authors would like to thank the Deanship of Scientific Research in King Saud University for funding and supporting this research through the initiative of DSR Graduate Students Research Support (GSR).

Conflicts of Interest: The authors declare no conflict of interest.

\section{References}

1. Alotaibi, M.O.; Sonbol, H.S.; Alwakeel, S.S.; Suliman, R.S.; Fodah, R.A.; Jaffal, A.S.A.; AlOthman, N.I.; Mohammed, A.E. Microbial diversity of some sabkha and desert sites in Saudi Arabia. Saudi J. Biol. Sci. 2020, 27, 2778-2789. [CrossRef] [PubMed]

2. Al-Amoudi, O.S.B. Studies on Soil-Foundation Interaction in the Sabkha Environment of Eastern Province of Saudi Arabia. Ph.D. Thesis, King Fahd University of Petroleum and Minerals, Dhahran, Saudi Arabia, 1992.

3. Abd-ElGawad, A.M.; Assaeed, A.M.; Al-Rowaily, S.L.; Dar, B.M.; Malik, J.A. Moisture and Salinity Drive the Vegetation Composition of Wadi Hargan, Riyadh, Saudi Arabia. Diversity 2021, 13, 587. [CrossRef]

4. Al-Fredan, M.A. Sand dune and sabkha vegetations of Eastern Saudi Arabia. Int. J. Bot. 2008, 4, 196-204. [CrossRef]

5. Etesami, H.; Noori, F. Soil salinity as a challenge for sustainable agriculture and bacterial-mediated alleviation of salinity stress in crop plants. In Saline Soil-Based Agriculture by Halotolerant Microorganisms; Springer: Berlin/Heidelberg, Germany, 2019; pp. 1-22.

6. Ivushkin, K.; Bartholomeus, H.; Bregt, A.K.; Pulatov, A.; Kempen, B.; De Sousa, L. Global mapping of soil salinity change. Remote Sens. Environ. 2019, 231, 111260. [CrossRef]

7. Din, B.U.; Sarfraz, S.; Xia, Y.; Kamran, M.A.; Javed, M.T.; Sultan, T.; Munis, M.F.H.; Chaudhary, H.J. Mechanistic elucidation of germination potential and growth of wheat inoculated with exopolysaccharide and ACC-deaminase producing Bacillus strains under induced salinity stress. Ecotoxicol. Environ. Saf. 2019, 183, 109466.

8. Lakhdar, A.; Rabhi, M.; Ghnaya, T.; Montemurro, F.; Jedidi, N.; Abdelly, C. Effectiveness of compost use in salt-affected soil. J. Hazard. Mater. 2009, 171, 29-37. [CrossRef] [PubMed]

9. Munns, R.; Tester, M. Mechanisms of salinity tolerance. Annu. Rev. Plant Biol. 2008, 59, 651-681. [CrossRef] [PubMed] 
10. Ali, S.; Rizwan, M.; Qayyum, M.F.; Ok, Y.S.; Ibrahim, M.; Riaz, M.; Arif, M.S.; Hafeez, F.; Al-Wabel, M.I.; Shahzad, A.N. Biochar soil amendment on alleviation of drought and salt stress in plants: A critical review. Environ. Sci. Pollut. Res. 2017, 24, 12700-12712. [CrossRef] [PubMed]

11. Nan, X.; Huihui, Z.; Haixiu, Z.; Yining, W.; Jinbo, L.; Li, X.; Zepeng, Y.; Wenxu, Z.; Yi, Q.; Guangyu, S. The response of photosynthetic functions of F1 cutting seedlings from Physocarpus amurensis Maxim ( $\left(\right.$ ) $\times$ Physocarpus opulifolius "Diabolo" $\left(\sigma^{\top}\right)$ and the parental seedlings to salt stress. Front. Plant Sci. 2018, 9, 714. [CrossRef] [PubMed]

12. Yildiz, M.; Poyraz, İ.; Çavdar, A.; Özgen, Y.; Beyaz, R. Plant Responses to Salt Stress. In Plant Breeding-Current Future Views; Intechopen: London, UK, 2020.

13. Kumar, S.; Li, G.; Yang, J.; Huang, X.; Ji, Q.; Liu, Z.; Ke, W.; Hou, H. Effect of salt stress on growth, physiological parameters, and ionic concentration of water dropwort (Oenanthe javanica) cultivars. Front. Plant Sci. 2021, 12, 660409. [CrossRef] [PubMed]

14. Fayaz, F.; Zahedi, M. Beneficial effects of arbuscular mycorrhizal fungi on wheat (Triticum aestivum L.) nutritional status and tolerance indices under soil salinity stress. J. Plant Nutr. 2021, 45, 185-201. [CrossRef]

15. Liang, S.; Jiang, Y.; Li, M.; Zhu, W.; Xu, N.; Zhang, H. Improving plant growth and alleviating photosynthetic inhibition from salt stress using AMF in alfalfa seedlings. J. Plant Interact. 2019, 14, 482-491. [CrossRef]

16. Sofy, M.R.; Aboseidah, A.A.; Heneidak, S.A.; Ahmed, H.R. ACC deaminase containing endophytic bacteria ameliorate salt stress in Pisum sativum through reduced oxidative damage and induction of antioxidative defense systems. Environ. Sci. Pollut. Res. 2021, 28, 40971-40991. [CrossRef] [PubMed]

17. Sofy, M.; Mohamed, H.; Dawood, M.; Abu-Elsaoud, A.; Soliman, M. Integrated usage of Trichoderma harzianum and biochar to ameliorate salt stress on spinach plants. Arch. Agron. Soil Sci. 2021, 1-22. [CrossRef]

18. Wu, H.; Shabala, L.; Zhou, M.; Stefano, G.; Pandolfi, C.; Mancuso, S.; Shabala, S. Developing and validating a high-throughput assay for salinity tissue tolerance in wheat and barley. Planta 2015, 242, 847-857. [CrossRef]

19. Silva, P.C.C.; Azevedo Neto, A.D.d.; Gheyi, H.R.; Ribas, R.F.; Silva, C.R.d.R.; Cova, A.M.W. Salt tolerance induced by hydrogen peroxide priming on seed is related to improvement of ion homeostasis and antioxidative defense in sunflower plants. J. Plant Nutr. 2020, 44, 1207-1221. [CrossRef]

20. Spatafora, J.W.; Chang, Y.; Benny, G.L.; Lazarus, K.; Smith, M.E.; Berbee, M.L.; Bonito, G.; Corradi, N.; Grigoriev, I.; Gryganskyi, A. A phylum-level phylogenetic classification of zygomycete fungi based on genome-scale data. Mycologia 2016, 108, 1028-1046 [CrossRef]

21. Goddard, M.-L.; Belval, L.; Martin, I.R.; Roth, L.; Laloue, H.; Deglène-Benbrahim, L.; Valat, L.; Bertsch, C.; Chong, J. Arbuscular mycorrhizal symbiosis triggers major changes in primary metabolism together with modification of defense responses and signaling in both roots and leaves of Vitis vinifera. Front. Plant Sci. 2021, 25, 1675. [CrossRef]

22. Borde, M.; Dudhane, M.; Kulkarni, M. Role of arbuscular mycorrhizal fungi (AMF) in salinity tolerance and growth response in plants under salt stress conditions. In Mycorrhiza-Eco-Physiology, Secondary Metabolites, Nanomaterials; Springer: Berlin/Heidelberg, Germany, 2017; pp. 71-86.

23. Klinsukon, C.; Lumyong, S.; Kuyper, T.W.; Boonlue, S. Colonization by arbuscular mycorrhizal fungi improves salinity tolerance of eucalyptus (Eucalyptus camaldulensis) seedlings. Sci. Rep. 2021, 11, 4362. [CrossRef]

24. Lenoir, I.; Fontaine, J.; Sahraoui, A.L.-H. Arbuscular mycorrhizal fungal responses to abiotic stresses: A review. Phytochemistry 2016, 123, 4-15. [CrossRef]

25. Giovannini, L.; Palla, M.; Agnolucci, M.; Avio, L.; Sbrana, C.; Turrini, A.; Giovannetti, M. Arbuscular mycorrhizal fungi and associated microbiota as plant biostimulants: Research strategies for the selection of the best performing inocula. Agronomy 2020, 10, 106. [CrossRef]

26. Wang, F.-Y.; Liu, R.-J.; Lin, X.-G.; Zhou, J.-M. Arbuscular mycorrhizal status of wild plants in saline-alkaline soils of the Yellow River Delta. Mycorrhiza 2004, 14, 133-137. [PubMed]

27. Smith, S.E.; Read, D.J. Mycorrhizal Symbiosis; Academic Press: Cambridge, MA, USA, 2010.

28. Evelin, H.; Devi, T.S.; Gupta, S.; Kapoor, R. Mitigation of salinity stress in plants by arbuscular mycorrhizal symbiosis: Current understanding and new challenges. Front. Plant Sci. 2019, 10, 470. [CrossRef]

29. Porcel, R.; Aroca, R.; Ruiz-Lozano, J.M. Salinity stress alleviation using arbuscular mycorrhizal fungi. A review. Agron. Sustain. Dev. 2012, 32, 181-200. [CrossRef]

30. Hashem, A.; Abd_Allah, E.F.; Alqarawi, A.A.; Aldubise, A.; Egamberdieva, D. Arbuscular mycorrhizal fungi enhances salinity tolerance of Panicum turgidum Forssk by altering photosynthetic and antioxidant pathways. J. Plant Interact. 2015, 10, 230-242 [CrossRef]

31. Hashem, A.; Alqarawi, A.A.; Radhakrishnan, R.; Al-Arjani, A.-B.F.; Aldehaish, H.A.; Egamberdieva, D.; Abd_Allah, E.F. Arbuscular mycorrhizal fungi regulate the oxidative system, hormones and ionic equilibrium to trigger salt stress tolerance in Cucumis sativus L. Saudi J. Biol. Sci. 2018, 25, 1102-1114. [CrossRef] [PubMed]

32. Beltrano, J.; Ruscitti, M.; Arango, M.C.; Ronco, M. Effects of arbuscular mycorrhiza inoculation on plant growth, biological and physiological parameters and mineral nutrition in pepper grown under different salinity and p levels. J. Soil Sci. Plant Nutr. 2013, 13, 123-141. [CrossRef]

33. Porcel, R.; Redondo-Gómez, S.; Mateos-Naranjo, E.; Aroca, R.; Garcia, R.; Ruiz-Lozano, J.M. Arbuscular mycorrhizal symbiosis ameliorates the optimum quantum yield of photosystem II and reduces non-photochemical quenching in rice plants subjected to salt stress. J. Plant Physiol. 2015, 185, 75-83. [CrossRef] [PubMed] 
34. Assaeed, A.M.; Al-Doss, A.A. Seedling competition of Lasiurus scindicus and Rhazya stricta in response to water stress. J. Arid. Environ. 2001, 49, 315-320. [CrossRef]

35. Cunningham, P.L. Plants included in the diet of Arabian sand gazelle (Reem) from Saudi Arabia. J. King Saud Univ.-Sci. 2013, 25, 167-173. [CrossRef]

36. Sanadya, S.K.; Shekhawat, S.S.; Sahoo, S. Sewan Grass: A Potential Forage Grass in Arid Environments. In Grasses and GrasslandNew Perspectives; Intechopen: London, UK, 2021.

37. Al-Rowaily, S.L.; Abd-ElGawad, A.M.; Alghanem, S.M.; Al-Taisan, W.A.A.; El-Amier, Y.A. Nutritional Value, Mineral Composition, Secondary Metabolites, and Antioxidant Activity of Some Wild Geophyte Sedges and Grasses. Plants 2019, 8, 569. [CrossRef]

38. Chaudhary, S.A.; Al-Jowaid, A.A.A. Vegetation of the Kingdom of Saudi Arabia; National Agricultural and Water Research Center, Ministry of Agriculture And Water: Ibaraki, Saudi Arabia, 1999.

39. Chauhan, S.S. Desertification control and management of land degradation in the Thar desert of India. Environmentalist 2003, 23, 219-227. [CrossRef]

40. Naz, N.; Rafique, T.; Hameed, M.; Ashraf, M.; Batool, R.; Fatima, S. Morpho-anatomical and physiological attributes for salt tolerance in sewan grass (Lasiurus scindicus Henr.) from Cholistan Desert, Pakistan. Acta Physiol. Plant. 2014, 36, 2959-2974. [CrossRef]

41. Gadi, B.; Goswami, B. Effect of salt stress on early seedling growth and chlorophyll stability index of Lasiurus sindicus Henr: Endemic to Indian Thar desert. Biochem. Cell Arch. 2016, 16, 103-106.

42. El-Keblawy, A.; Al-Ansari, F.; Al-Shamsi, N. Effects of temperature and light on salinity tolerance during germination in two desert glycophytic grasses, Lasiurus scindicus and Panicum turgidum. Grass Forage Sci. 2011, 66, 173-182. [CrossRef]

43. Naz, N.; Batool, R.; Fatima, S.; Hameed, M.; Ashraf, M.; Ahmad, F.; Ahmad, M.S.A. Adaptive components of tolerance to salinity in a saline desert grass Lasiurus scindicus Henrard. Ecol. Res. 2015, 30, 429-438. [CrossRef]

44. Ashraf, M.; Hameed, M.; Arshad, M.; Ashraf, Y.; Akhtar, K. Salt tolerance of some potential forage grasses from Cholistan desert of Pakistan. In Ecophysiology of High Salinity Tolerant Plants; Springer: Berlin/Heidelberg, Germany, 2008; pp. 31-54.

45. Estrada, B.; Aroca, R.; Barea, J.M.; Ruiz-Lozano, J.M. Native arbuscular mycorrhizal fungi isolated from a saline habitat improved maize antioxidant systems and plant tolerance to salinity. Plant Sci. 2013, 201, 42-51. [CrossRef] [PubMed]

46. Outamamat, E.; Bourhia, M.; Dounas, H.; Salamatullah, A.M.; Alzahrani, A.; Alyahya, H.K.; Albadr, N.A.; Al Feddy, M.N.; Mnasri, B.; Ouahmane, L. Application of Native or Exotic Arbuscular Mycorrhizal Fungi Complexes and Monospecific Isolates from Saline Semi-Arid Mediterranean Ecosystems Improved Phoenix dactylifera's Growth and Mitigated Salt Stress Negative Effects. Plants 2021, 10, 2501. [CrossRef] [PubMed]

47. Gerdemann, J.; Nicolson, T.H. Spores of mycorrhizal Endogone species extracted from soil by wet sieving and decanting. Trans. Br. Mycol. Soc. 1963, 46, 235-244. [CrossRef]

48. Walker, C. Spore Extraction by Centrifugation-Sugar Flotation; Biological Research and Imaging Laboratory: Hampshire, UK, 1997.

49. Redecker, D.; Schüßler, A.; Stockinger, H.; Stürmer, S.L.; Morton, J.B.; Walker, C. An evidence-based consensus for the classification of arbuscular mycorrhizal fungi (Glomeromycota). Mycorrhiza 2013, 23, 515-531. [CrossRef] [PubMed]

50. Schüssler, A.; Walker, C. The Glomeromycota: A Species List with New Families and New Gener. In The Glomeromycota; CreateSpace Independent Publishing Platform: Scotts Valley, CA, USA, 2010.

51. Phillips, J.M.; Hayman, D. Improved procedures for clearing roots and staining parasitic and vesicular-arbuscular mycorrhizal fungi for rapid assessment of infection. Trans. Br. Mycol. Soc. 1970, 55, 158-161. [CrossRef]

52. Trouvelot, A.; Kough, J.; Gianinazzi-Pearson, V. Evaluation of VA infection levels in root systems. Research for estimation methods having a functional significance. Physiol. Genet. Asp. Mycorrhizae 1986, 1, 217-221.

53. Al-Qarawi, A.; Mridha, M.; Alghamdi, O. Diversity of structural colonization and spore population of arbuscular mycorrhizal fungi in some plants from Riyadh, Saudi Arabia. J. Pure Appl. Microbiol. 2012, 6, 1119-1125.

54. Arnon, D.I. Copper enzymes in isolated chloroplasts. Polyphenoloxidase in Beta vulgaris. Plant Physiol. 1949, 24, 1. [CrossRef] [PubMed]

55. Rajput, R.; Patil, R. The comparative study on spectrophotometric analysis of chlorophyll and carotenoids pigments from non-leguminous fodder crops. Int. J. Innov. Sci. Eng. Technol. 2017, 4, 140-148.

56. Bates, L.S.; Waldren, R.P.; Teare, I. Rapid determination of free proline for water-stress studies. Plant Soil 1973, 39, $205-207$. [CrossRef]

57. Ainsworth, E.A.; Gillespie, K.M. Estimation of total phenolic content and other oxidation substrates in plant tissues using Folin-Ciocalteu reagent. Nat. Protoc. 2007, 2, 875-877. [CrossRef] [PubMed]

58. Sergiev, I.; Alexieva, V.; Karanov, E. Effect of spermine, atrazine and combination between them on some endogenous protective systems and stress markers in plants. Comptes Rendus De L'académie Bulg. Des Sci. 1997, 51, 121-124.

59. Bradford, M.M. A rapid and sensitive method for the quantitation of microgram quantities of protein utilizing the principle of protein-dye binding. Anal. Biochem. 1976, 72, 248-254. [CrossRef]

60. Marklund, S.; Marklund, G. Involvement of the superoxide anion radical in the autoxidation of pyrogallol and a convenient assay for superoxide dismutase. Eur. J. Biochem. 1974, 47, 469-474. [CrossRef]

61. Aebi, H. Catalase in vitro. Methods Enzymol. 1984, 105, 121-126. [PubMed]

62. Nakano, Y.; Asada, K. Hydrogen peroxide is scavenged by ascorbate-specific peroxidase in spinach chloroplasts. Plant Cell Physiol. $1981,22,867-880$ 
63. Schaedle, M.; Bassham, J.A. Chloroplast glutathione reductase. Plant Physiol. 1977, 59, 1011-1012. [CrossRef] [PubMed]

64. Pritchard, S.G.; Ju, Z.; van Santen, E.; Qiu, J.; Weaver, D.B.; Prior, S.A.; Rogers, H.H. The influence of elevated $\mathrm{CO}_{2}$ on the activities of antioxidative enzymes in two soybean genotypes. Funct. Plant Biol. 2000, 27, 1061-1068. [CrossRef]

65. Miransari, M. Contribution of arbuscular mycorrhizal symbiosis to plant growth under different types of soil stress. Plant Biol. 2010, 12, 563-569. [CrossRef] [PubMed]

66. Yarahmadi, M.A.; Shahsavani, S.; Akhyani, A.; Dorostkar, V. Pomegranate growth affected by arbuscular mycorrhizae, phosphorus fertilizer, and irrigation water salinity. Commun. Soil Sci. Plant Anal. 2018, 49, 478-488. [CrossRef]

67. Krishnamoorthy, R.; Kim, K.; Kim, C.; Sa, T. Changes of arbuscular mycorrhizal traits and community structure with respect to soil salinity in a coastal reclamation land. Soil Biol. Biochem. 2014, 72, 1-10. [CrossRef]

68. Sharifi, M.; Ghorbanli, M.; Ebrahimzadeh, H. Improved growth of salinity-stressed soybean after inoculation with salt pre-treated mycorrhizal fungi. J. Plant Physiol. 2007, 164, 1144-1151. [CrossRef]

69. Aliasgharzadeh, N.; Rastin, S.N.; Towfighi, H.; Alizadeh, A. Occurrence of arbuscular mycorrhizal fungi in saline soils of the Tabriz Plain of Iran in relation to some physical and chemical properties of soil. Mycorrhiza 2001, 11, 119-122. [CrossRef] [PubMed]

70. Alqarawi, A.A.; Abd Allah, E.; Hashem, A. Alleviation of salt-induced adverse impact via mycorrhizal fungi in Ephedra aphylla Forssk. J. Plant Interact. 2014, 9, 802-810. [CrossRef]

71. Elhindi, K.M.; El-Din, A.S.; Elgorban, A.M. The impact of arbuscular mycorrhizal fungi in mitigating salt-induced adverse effects in sweet basil (Ocimum basilicum L.). Saudi J. Biol. Sci. 2017, 24, 170-179. [CrossRef] [PubMed]

72. Sharif, P.; Seyedsalehi, M.; Paladino, O.; Van Damme, P.; Sillanpää, M.; Sharifi, A. Effect of drought and salinity stresses on morphological and physiological characteristics of canola. Int. J. Environ. Sci. Technol. 2018, 15, 1859-1866. [CrossRef]

73. Meriem, B.F.; Kaouther, Z.; Chérif, H.; Tijani, M.; André, B. Effect of priming on growth, biochemical parameters and mineral composition of different cultivars of coriander (Coriandrum sativum L.) under salt stress. J. Stress Physiol. Biochem. 2014, 10, 84-109.

74. Taibi, K.; Taibi, F.; Abderrahim, L.A.; Ennajah, A.; Belkhodja, M.; Mulet, J.M. Effect of salt stress on growth, chlorophyll content, lipid peroxidation and antioxidant defence systems in Phaseolus vulgaris L. S. Afr. J. Bot. 2016, 105, 306-312. [CrossRef]

75. Guo, R.; Zhou, J.; Hao, W.; Gu, F.; Liu, Q.; Li, H.; Xia, X.; Mao, L. Germination, growth, chlorophyll fluorescence and ionic balance in linseed seedlings subjected to saline and alkaline stresses. Plant Prod. Sci. 2014, 17, 20-31. [CrossRef]

76. Abeer, H.; Abd_Allah, E.; Alqarawi, A.; El-Didamony, G.; Alwhibi, M.; Egamberdieva, D.; Ahmad, P. Alleviation of adverse impact of salinity on faba bean (Vicia faba L.) by arbuscular mycorrhizal fungi. Pak. J. Bot. 2014, 46, $2003-2013$.

77. Ahmad, P.; Abdel Latef, A.A.; Hashem, A.; Abd_Allah, E.F.; Gucel, S.; Tran, L.-S.P. Nitric oxide mitigates salt stress by regulating levels of osmolytes and antioxidant enzymes in chickpea. Front. Plant Sci. 2016, 7, 347. [CrossRef] [PubMed]

78. Wu, N.; Li, Z.; Wu, F.; Tang, M. Comparative photochemistry activity and antioxidant responses in male and female Populus cathayana cuttings inoculated with arbuscular mycorrhizal fungi under salt. Sci. Rep. 2016, 6, 37663. [CrossRef] [PubMed]

79. Mehr, Z.; Khajeh, H.; Bahabadi, S.; Sabbagh, S. Changes on proline, phenolic compounds and activity of antioxidant enzymes in Anethum graveolens L. under salt stress. Int. J. Agron. Plant Prod. 2012, 3, 710-715.

80. Rezazadeh, A.; Ghasemnezhad, A.; Barani, M.; Telmadarrehei, T. Effect of salinity on phenolic composition and antioxidant activity of artichoke (Cynara scolymus L.) leaves. Res. J. Med. Plant 2012, 6, 245-252. [CrossRef]

81. Bors, W.; Michel, C.; Saran, M. Flavonoid antioxidants: Rate constants for reactions with oxygen radicals. Methods Enzymol. 1994, 234, 420-429. [PubMed]

82. Sarabi, B.; Bolandnazar, S.; Ghaderi, N.; Tabatabaei, S.J. Multivariate analysis as a tool for studying the effects of salinity in different melon landraces at germination stage. Not. Bot. Horti Agrobot. 2016, 44, 264-271. [CrossRef]

83. Ait-El-Mokhtar, M.; Baslam, M.; Ben-Laouane, R.; Anli, M.; Boutasknit, A.; Mitsui, T.; Wahbi, S.; Meddich, A. Alleviation of detrimental effects of salt stress on date palm (Phoenix dactylifera L.) by the application of arbuscular mycorrhizal fungi and/or compost. Front. Sustain. Food Syst. 2020, 4, 131. [CrossRef]

84. Alscher, R.G.; Erturk, N.; Heath, L.S. Role of superoxide dismutases (SODs) in controlling oxidative stress in plants. J. Exp. Bot. 2002, 53, 1331-1341. [CrossRef] [PubMed]

85. Imlay, J.A.; Linn, S. DNA damage and oxygen radical toxicity. Science 1988, 240, 1302-1309. [CrossRef] [PubMed]

86. Hashem, A.; Abd_Allah, E.F.; Alqarawi, A.A.; Wirth, S.; Egamberdieva, D. Arbuscular mycorrhizal fungi alleviate salt stress in lupine (Lupinus termis Forsik) through modulation of antioxidant defense systems and physiological traits. Legume Res. -Int. J. 2016, 39, 198-207. [CrossRef]

87. Chandrasekaran, M.; Boopathi, T.; Manivannan, P. Comprehensive Assessment of Ameliorative Effects of AMF in Alleviating Abiotic Stress in Tomato Plants. J. Fungi 2021, 7, 303. [CrossRef] [PubMed]

88. Ahmad, P.; Alyemeni, M.N.; Al-Huqail, A.A.; Alqahtani, M.A.; Wijaya, L.; Ashraf, M.; Kaya, C.; Bajguz, A. Zinc oxide nanoparticles application alleviates arsenic (As) toxicity in soybean plants by restricting the uptake of as and modulating key biochemical attributes, antioxidant enzymes, ascorbate-glutathione cycle and glyoxalase system. Plants 2020, 9, 825. [CrossRef] [PubMed] 